\title{
Declarations of interest by members of Health Canada's special advisory committees and panels: a descriptive study
}

\author{
Joel Lexchin MSc MD
}

Abstract

Background: Health Canada supplements its in-house expertise on pharmacotherapy and pharmaceutical policy through the use of scientific/expert advisory committees and scientific/expert advisory panels. This study was undertaken to examine the interests of the members of these Health Canada advisory bodies.

Methods: This was an observational study of the financial and intellectual interests of members of Health Canada's scientific/expert advisory committees and panels. The following information was extracted from Health Canada websites in December 2018: member's name, name of committee/panel, direct and indirect financial interests, and intellectual interests. Information extracted about the committees and panels included the number of meetings for which a record of proceedings was available and the topics discussed at the meetings.

Results: Of 81 unique committee and panel members, 12 declared a direct financial interest, 56 an indirect financial interest and 65 an intellectual interest. Five of 11 committees and panels had people who declared a direct financial interest. All 11 advisory bodies had members who declared indirect financial interests $(n=62)$ and intellectual interests $(n=81)$. Six of the 11 committees and panels had a majority of members who declared a direct or indirect financial interest. In the 10 advisory body meetings for which information was available, individual products were rarely discussed but recommendations from all but 1 of the meetings could potentially have affected sales.

Interpretation: Only a minority of members of Health Canada's advisory committees and panels declared direct financial interests but the majority of members of a majority of the advisory bodies declared indirect financial and intellectual interests. Because of the lack of individual voting records it was not possible to determine if financial or intellectual interests influenced voting patterns.

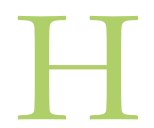
ealth Canada supplements its in-house expertise on pharmacotherapy and pharmaceutical policy through the use of scientific/expert advisory committees (SACs) and scientific/expert advisory panels (SAPs). SACs are standing committees that provide Health Canada with recommendations about policy issues for drugs and medical devices in specific therapeutic areas or classes. ${ }^{1}$ Health Canada uses ad hoc SAPs for technical advice about specific drug and medical device issues. ${ }^{2}$ People interested in serving on a committee or a panel fill out an online application form listing their qualifications and expertise ${ }^{3}$ and Health Canada chooses members from this list for its various committees and panels.

For individuals to be considered for an appointment to committees or panels, Health Canada requires them to complete the Affiliations and Interests Declaration Form for Advisory Body Members and disclose all affiliations and interests, including any direct financial interest of relevance to the mandate of the committee or panel, indirect financial interests, intellectual interests and "other" interests. ${ }^{4,5}$ People with a direct financial interest in the outcome of a review of a product cannot be a committee or panel member when the advisory body's mandate is solely to provide advice on specific matters relating to the review, but they can be members if the broader mandate encompasses matters of policy, management or program development.

In the United States, conflicts of interest are associated with the voting patterns of members of Food and Drug Administration (FDA) advisory committees. ${ }^{6}$ Whether the same applies to Canada is not known. This study was undertaken to examine the declared interests of Health Canada committee and panel members and to determine if their interests were associated with their voting patterns.

Competing interests: See end of article.

This article has been peer reviewed.

Correspondence to: Joel Lexchin, jlexchin@yorku.ca

CMAJ Open 2019. DOI:10.9778/cmajo.20190010 


\section{Methods}

\section{Source of data}

Health Canada treats completed copies of the Affiliations and Interests Declaration Form for Advisory Body Members ${ }^{4}$ as confidential, but it does make public a Summary of Expertise, Experience and Affiliations and Interests for individual members of currently active SACs and SAPs and these summaries define each of the 4 types of interests (direct and indirect financial, intellectual and other interests). Questions about direct financial interests on the Affiliations and Interests Declaration Form for Advisory Body Members ask the respondent to name the company and the type of interest but not its monetary value. Questions about indirect financial interests on the same form ask the respondent to name the company and the approximate amount of money received. Information about company names, the type of undertaking that the respondent has with particular companies and their monetary value are not reported in the Summary of Expertise, Experience and Affiliations and Interests.

For each active SAC and SAP, all of the available information from the summaries was extracted by the author for each member: name, name of committee/panel, perspective/sector, and declaration of interests in each of the 4 categories listed in Table 1.7,8 Information about the SAC/SAP was extracted on Dec. 15, 2018, by the author, including the following: number of meetings, number and date of meetings for which a record of proceedings was available (complete transcripts of the meetings are not available), topics discussed at meetings and recommendations from the SAC/SAP. A second person (C.O., a retired family physician) verified all of the extracted data and differences were resolved by discussion. Information was current as of Dec. 15, 2018, the date of data collection.

\section{Data analysis}

For the purposes of analysis, the 3 different types of indirect financial interests were combined into 1 category as were the 3 different types of intellectual interests. Descriptive data are reported as counts: the number of individual SAC/SAP members from different perspectives/sectors and the distribution of interests by perspective/sector, the number of SACs/SAPs, the number of members of each SAC/SAP and the distribution of interests. Because the chairs of SACs/SAPs may have more influence than regular panel members the number and type of their interest declarations were analyzed separately. The topics discussed in the SAC/SAP meetings and the recommendations from the SACs/SAPs about those topics are also reported. Multiple declarations from the same person were treated as discrete declarations.

\section{Ethics approval}

All data were publicly available and no patients were involved; therefore, ethics approval was not sought.

\section{Resullts}

There were 3 active SACs and 8 active SAPs on Dec. 15, 2018. Information about all 4 types of interests (direct and indirect financial, intellectual and other) was available for all 81 unique individuals who were members of these SACs and SAPs as of Dec. 15, 2018. Sixty-nine sat on a single SAC/SAP, 7 on 2, 4 on 3 and 1 on 4 SACs/SAPs. There were also 7 inactive SACs ( 4 had completed their mandate and 3 had been cancelled $^{8}$ ) and 10 SAPs that had completed their mandate. ${ }^{7}$ Health Canada does not provide a list of the membership of these inactive committees and panels. People who sat on more

\begin{tabular}{|c|c|}
\hline Type of interest & Description \\
\hline Direct financial interests & $\begin{array}{l}\text { Current employment, investments in companies, partnerships, equity, royalties, joint ventures, trusts, real } \\
\text { property, stocks, shares or bonds, with the regulated industry }\end{array}$ \\
\hline \multirow[t]{3}{*}{ Indirect financial interests } & $\begin{array}{l}\text { Within the past } 5 \text { years, payment from regulated industry for work done or being done, including past } \\
\text { employment, contracts or consulting; or financial support including research support, personal education } \\
\text { grants, contributions, fellowships, sponsorships and honoraria }\end{array}$ \\
\hline & $\begin{array}{l}\text { Within the past } 5 \text { years, materials, discounted products, gifts or other benefits, or attendance at meetings } \\
\text { where all or part of the travel and accommodation costs were provided by the regulated industry }\end{array}$ \\
\hline & $\begin{array}{l}\text { Within the last } 3 \text { years, grants or other funding from the regulated industry to any of the organizations where } \\
\text { you are currently employed or participate in internal decision-making }\end{array}$ \\
\hline \multirow[t]{3}{*}{ Intellectual interests } & $\begin{array}{l}\text { Within the last } 5 \text { years, any formal advice or opinion to industry, a government organization or a } \\
\text { nongovernment organization on a matter of relevance to the scientific advisory committee or scientific } \\
\text { advisory panel }\end{array}$ \\
\hline & $\begin{array}{l}\text { Within the last } 5 \text { years, any published or publicly stated point of view on issues of relevance to the scientific } \\
\text { advisory committee or scientific advisory panel mandate }\end{array}$ \\
\hline & $\begin{array}{l}\text { Current professional or volunteer affiliations such as membership in professional societies, lobbying, public } \\
\text { interest or advocacy groups, of relevance to the scientific advisory committee or scientific advisory panel }\end{array}$ \\
\hline Other interests & $\begin{array}{l}\text { Any other affiliations and interests or potential circumstances that might give a well-informed member of the } \\
\text { public reasonable grounds for concern regarding the integrity and objectivity of your participation }\end{array}$ \\
\hline
\end{tabular}


than $1 \mathrm{SAC/SAP}$ sometimes made different declarations of interest, resulting in 99 unique declarations of interest. Health Canada does not give the dates when the declarations were made. (Supplementary File 1 available on request from the author contains the complete data set for this study.)

Of the 81 unique individuals on SACs/SAPs, 12 declared a direct financial interest, 56 an indirect financial interest, 65 an intellectual interest and 4 an "other" (undefined) interest. The majority of the advisory body members from all perspectives/sectors had intellectual interests, and the majority of members from all perspectives/sectors except the academia plus research perspective/sector and the pharmacy perspective/sector had indirect financial interests. Direct financial interests were found most often among members from the academia perspective/sector and the academia plus health professional perspective/sector (Table 2). Fifty-seven members had either a direct or indirect financial interest and 10 members had no interests of any kind (data not shown).

Only 1 of the 11 chairs had a direct financial interest whereas 8 had an indirect financial interest and a similar number had an intellectual interest (data not shown).

SACs and SAPs had between 4 and 21 members. Five of the 11 SACs/SAPs had at least 1 member with a direct financial interest. All 11 committees had members with indirect financial interests $(n=62)$ and intellectual interests $(n=81)$. Six of the 11 SACs/SAPs had a majority of members with a direct or indirect financial interest and 9 had a majority of members with an intellectual interest. No SAC/SAP had a membership that was entirely free of any type of financial interest. Only 1 SAC/SAP had a minority of members with intellectual interests (Table 3 ).
The 11 SACs/SAPs had a total of 30 meetings (range 1-11) but a record of proceedings was only available for 10 meetings taking place between June 2011 and November 2017. These meetings only discussed 2 specific products (Diclectin and isotretinoin). Table 4 presents the recommendations from the committees and panels. Some recommendations, such as the one not to change the labelling for Diclectin, could have had a positive effect on sales, whereas others, such as adding warnings about fluoroquinolones, could have had a negative effect.

\section{Interpretation}

A minority of members of committees and panels declared direct financial interests whereas the majority declared indirect financial and intellectual interests, regardless of their perspectives/sectors, with the exception of indirect financial interests in 2 perspectives/sectors. Ten people declared no interests of any kind. Only a minority of chairs declared a direct financial interest, but the majority declared indirect financial interests. The majority of committees and panels had a majority of members who declared indirect financial and intellectual interests. More individuals declared intellectual interests than declared a combination of direct and indirect financial interests. Differences in declarations by people serving on multiple committees might be a consequence of making declarations at different times but since Health Canada does not give the dates of the declarations this hypothesis cannot be further investigated.

Some recommendations from SACs/SAPs could have had an effect on sales but because Health Canada does not publicly record the votes of individual members it was not possible to link interests with voting patterns.

Table 2: Interests declared, by perspective/sector

\begin{tabular}{|c|c|c|c|c|c|}
\hline \multirow[b]{2}{*}{ Perspective/sector } & \multirow{2}{*}{$\begin{array}{l}\text { Total no. of } \\
\text { members }\end{array}$} & \multicolumn{4}{|c|}{ No. of members; type of interest } \\
\hline & & Direct financial & Indirect financial & Intellectual & Other \\
\hline Academia & 13 & 3 & 10 & 10 & 0 \\
\hline $\begin{array}{l}\text { Academia + health } \\
\text { professional }\end{array}$ & 22 & 3 & 20 & 18 & 1 \\
\hline $\begin{array}{l}\text { Academia + health } \\
\text { professional + research }\end{array}$ & 8 & 0 & 6 & 7 & 1 \\
\hline Academia + research & 8 & 1 & 3 & 5 & 0 \\
\hline $\begin{array}{l}\text { Health professional; } \\
\text { health professional + } \\
\text { research }\end{array}$ & 17 & 1 & 11 & 12 & 2 \\
\hline $\begin{array}{l}\text { Industry; } \\
\text { academia + industry }\end{array}$ & 3 & 2 & 2 & 3 & 0 \\
\hline Infectious diseases & 4 & 1 & 2 & 4 & 0 \\
\hline Patient/consumer & 4 & 1 & 2 & 4 & 0 \\
\hline Pharmacy & 2 & 0 & 0 & 2 & 0 \\
\hline Total & 81 & 12 & 56 & 65 & 4 \\
\hline
\end{tabular}




\begin{tabular}{|c|c|c|c|c|c|c|}
\hline \multirow[b]{2}{*}{ Advisory body } & \multirow[b]{2}{*}{$\begin{array}{l}\text { Total no. of } \\
\text { declarations }\end{array}$} & \multicolumn{5}{|c|}{ No. (\%) of declarations; type of interest } \\
\hline & & $\begin{array}{c}\text { Direct } \\
\text { financial } \\
\text { interest }\end{array}$ & $\begin{array}{l}\text { Indirect } \\
\text { financial } \\
\text { interest }\end{array}$ & $\begin{array}{c}\text { Direct or } \\
\text { indirect } \\
\text { financial } \\
\text { interest }\end{array}$ & $\begin{array}{l}\text { Intellectual } \\
\text { interest }\end{array}$ & $\begin{array}{l}\text { Other } \\
\text { interest }\end{array}$ \\
\hline Oncology therapies SAC & 21 & $3(14.3)$ & $18(85.7)$ & $18(85.7)$ & $16(76.2)$ & $2(9.5)$ \\
\hline $\begin{array}{l}\text { Pharmaceutical sciences and clinical } \\
\text { pharmacology SAC }\end{array}$ & 13 & $4(30.8)$ & $9(69.2)$ & $10(76.9)$ & $12(92.3)$ & $0(0)$ \\
\hline Respiratory and allergy therapies SAC & 19 & $3(15.8)$ & $14(73.7)$ & $14(73.7)$ & $16(84.2)$ & $0(0)$ \\
\hline Anti-infective therapies SAP & 6 & $1(16.7)$ & $2(33.3)$ & $2(33.3)$ & $6(100)$ & $0(0)$ \\
\hline $\begin{array}{l}\text { Bioequivalence requirements } \\
\text { for gender-specific drug products SAP }\end{array}$ & 7 & $0(0)$ & $4(57.1)$ & $4(57.1)$ & $6(85.7)$ & $0(0)$ \\
\hline $\begin{array}{l}\text { Bioequivalence requirements } \\
\text { for modified-release dosage forms SAP }\end{array}$ & 6 & $0(0)$ & $5(83.3)$ & 5 (83.3) & 5 (83.3) & $0(0)$ \\
\hline Diclectin SAP & 4 & $0(0)$ & $1(25.0)$ & $1(25.0)$ & $1(25.0)$ & $0(0)$ \\
\hline Opioid analgesic abuse SAP & 6 & $1(16.7)$ & $4(66.7)$ & $4(66.7)$ & $4(66.7)$ & $0(0)$ \\
\hline Opioid use and contraindications SAP & 6 & $0(0)$ & $1(16.7)$ & $1(16.7)$ & $6(100)$ & $2(33.3)$ \\
\hline Opioids SAP & 6 & $0(0)$ & $2(33.3)$ & $2(33.3)$ & $6(100)$ & $2(33.3)$ \\
\hline Isotretinoin risk management SAP & 5 & $0(0)$ & $2(40.0)$ & $2(40.0)$ & $3(60.0)$ & $0(0)$ \\
\hline Total & 99 & 12 & 62 & 63 & 81 & 6 \\
\hline
\end{tabular}

There is evidence that financial interests lead to systematic biases in scientific research ${ }^{9}$ whereas the same has not been shown for intellectual interests. Furthermore, financial interests are quantifiable whereas intellectual ones are innate characteristics of the researcher, ${ }^{10}$ and therefore the former are much easier to document and regulate.

Even the receipt of small amounts of money or the equivalent can affect behaviour. Meals valued at less than US\$20 are associated with higher prescribing rates for drugs made by the companies providing the meals. ${ }^{11}$ Research on voting patterns of people serving on FDA advisory committees shows an association between having financial ties solely to the firm sponsoring the drug under question or serving on advisory boards for sponsoring companies and pro-sponsor votes. ${ }^{6}$ The Institute of Medicine (now the National Academy of Medicine) in its report on conflict of interest in guidelines recommends that the chair of any panel should be free of all conflicts as should the majority of the members of the panel. ${ }^{12}$

Experts may not participate on FDA advisory committees if their financial conflict of interest (COI) is in excess of US\$50 000 but the FDA grants waivers under 1 of 3 conditions: (a) the COI is unlikely to "affect the integrity of the services," (b) the "need for the individual's services outweighs the potential for a COI" or (c) they will contribute "essential expertise." ${ }^{13}$ COI declarations and waivers are publicly available on the FDA website and financial COIs are reported in dollar ranges (e.g., \$0-\$5000, \$5001-\$10 000) ${ }^{14}$ and are available for each advisory committee meeting not just when people are appointed. The FDA can also exclude people from serving on committees for intellectual conflicts. ${ }^{15}$ The chair, members and expert advisors of the Commission on Human Medicines of the United Kingdom's Medicines and Healthcare products Regulatory Agency are governed by a 2006 code of practice that requires each member to make an annual declaration of interests in the pharmaceutical industry and the declarations are published annually. ${ }^{16}$ In Canada, CADTH requires expert committee and panel members to declare direct and indirect financial interests and intellectual interests. A summary of each member's expertise, experience, affiliations and conflict of interest declarations is publicly available on the CADTH website. The declaration form asks members for the name of the party with which they have a conflict and for the monetary value of the benefit in dollar ranges (e.g., \$0-\$5000, \$5001-\$10 000). ${ }^{17} \mathrm{Com}-$ pany names are disclosed on the website but not the monetary value of the benefits.

\section{Limitations}

The committees and panels that were examined are only a minority of the ones that Health Canada has used, and whether the results of this study can be applied to inactive SACs/SAPs is unknown. The interests that were declared and reported in the Summary of Expertise, Experience and Affiliations and Interests by individual members were stated on the date of their appointment and may not be current. In addition, the interests could not be verified by independent searching because not enough detail was provided in the declarations on the Health Canada website, including the absence of the date when the declarations were made. The lack of independent verification also means that it was not possible to determine if 


\begin{tabular}{|c|c|c|c|c|c|}
\hline $\begin{array}{l}\text { Committee or } \\
\text { panel }\end{array}$ & $\begin{array}{c}\text { No. of } \\
\text { meetings }\end{array}$ & $\begin{array}{l}\text { No. of meetings } \\
\text { where a record } \\
\text { of proceedings } \\
\text { was available }\end{array}$ & $\begin{array}{l}\text { Date(s) of } \\
\text { meeting(s) } \\
\text { where a } \\
\text { record of } \\
\text { proceedings } \\
\text { was available* }\end{array}$ & $\begin{array}{l}\text { Summary of topic(s) } \\
\text { discussed }\end{array}$ & Summary of recommendation(s) $\dagger$ \\
\hline $\begin{array}{l}\text { Oncology } \\
\text { therapies SAC }\end{array}$ & 7 & 1 & $\begin{array}{l}\text { August/ } \\
\text { September } \\
2011\end{array}$ & $\begin{array}{l}\text { - Regulations } \\
\text { prohibiting the use of } \\
\text { arsenic as an } \\
\text { ingredient in drugs } \\
\text { sold for human use }\end{array}$ & $\begin{array}{l}\text { - The section of the Food and Drugs Act that } \\
\text { prohibits the sale of drugs containing arsenic } \\
\text { should be revoked. }\end{array}$ \\
\hline $\begin{array}{l}\text { Pharmaceutical } \\
\text { sciences and } \\
\text { clinical } \\
\text { pharmacology } \\
\text { SAC }\end{array}$ & 4 & 0 & & & \\
\hline $\begin{array}{l}\text { Respiratory and } \\
\text { allergy therapies } \\
\text { SAC }\end{array}$ & 11 & 3 & $\begin{array}{l}\text { Mar. 14, } 2012 \\
\text { Oct. 26, } 2013 \\
\text { Feb. 23, } 2018\end{array}$ & $\begin{array}{l}\text { - Data requirements for } \\
\text { safety and } \\
\text { effectiveness of } \\
\text { subsequent market } \\
\text { entry inhaled } \\
\text { products for use in } \\
\text { the treatment of } \\
\text { asthma }\end{array}$ & $\begin{array}{l}\text { - An in vitro data package is adequate in lieu of } \\
\text { clinical data to demonstrate bioequivalence of } \\
\text { a subsequent market entry budesonide } \\
\text { suspension for inhalation using a suitable } \\
\text { nebulizer. } \\
\text { - Depending on the type of product, clinical } \\
\text { outcome studies using FEV1 are acceptable as } \\
\text { long as a difference in the mean of at least } 12 \% \\
\text { is demonstrated. }\end{array}$ \\
\hline $\begin{array}{l}\text { Anti-infective } \\
\text { therapies SAP }\end{array}$ & 1 & 1 & Oct. 6, 2016 & $\begin{array}{l}\text { - Issues around the } \\
\text { safety and efficacy of } \\
\text { fluoroquinolones for } \\
\text { different indications }\end{array}$ & $\begin{array}{l}\text { - The product monograph for fluoroquinolones } \\
\text { should include a statement about disabling and } \\
\text { potentially irreversible persistent adverse } \\
\text { reactions. } \\
\text { - Fluoroquinolones should not be used for acute } \\
\text { sinusitis of less than } 7 \text { d duration. }\end{array}$ \\
\hline $\begin{array}{l}\text { Bioequivalence } \\
\text { requirements for } \\
\text { gender-specific } \\
\text { drug products } \\
\text { SAP }\end{array}$ & 1 & 1 & June 22, 2011 & $\begin{array}{l}\text { - Requirements for } \\
\text { market authorization } \\
\text { of a second entry or } \\
\text { subsequent entry } \\
\text { gender-specific drug } \\
\text { product }\end{array}$ & $\begin{array}{l}\text { - The current practice of using only males, males } \\
\text { and females or only females for bioequivalence } \\
\text { studies should be continued. }\end{array}$ \\
\hline $\begin{array}{l}\text { Bioequivalence } \\
\text { requirements for } \\
\text { modified-release } \\
\text { dosage forms } \\
\text { SAP }\end{array}$ & 1 & 0 & & & \\
\hline Diclectin SAP & 1 & 1 & June 2, 2016 & $\begin{array}{l}\text { - Data from study of } \\
\text { Diclectin }\end{array}$ & $\begin{array}{l}\text { - The panel would not recommend any changes } \\
\text { to the current labelling of Diclectin for the } \\
\text { management of nausea and vomiting of } \\
\text { pregnancy. }\end{array}$ \\
\hline $\begin{array}{l}\text { Opioid analgesic } \\
\text { abuse SAP }\end{array}$ & 1 & 0 & & & \\
\hline $\begin{array}{l}\text { Opioid use and } \\
\text { contraindications } \\
\text { SAP }\end{array}$ & 1 & 1 & Mar. 24, 2017 & $\begin{array}{l}\text { - Information about } \\
\text { opioids that should } \\
\text { be included in } \\
\text { product monograph } \\
\text { - Should low-dose } \\
\text { codeine products be } \\
\text { made prescription- } \\
\text { only? }\end{array}$ & $\begin{array}{l}\text { - Information about a threshold dose for chronic } \\
\text { noncancer pain should be in the dosing and } \\
\text { administration section of the product } \\
\text { monograph in such a way as to draw the } \\
\text { attention of the prescriber. } \\
\text { - The indication for extended/long-acting opioids } \\
\text { should be changed to say that patients should } \\
\text { first have tried a nonopioid medication. } \\
\text { - Prescriptions for opioids for acute pain should } \\
\text { be limited to } 3 \text { d. } \\
\text { - No changes should be made to the } \\
\text { nonprescription status of low-dose codeine } \\
\text { products at present. }\end{array}$ \\
\hline
\end{tabular}


Table 4 (part 2 of 2): Topics discussed at SAC/SAP meetings and summary of recommendations

\begin{tabular}{|c|c|c|c|c|c|}
\hline $\begin{array}{l}\text { Committee or } \\
\text { panel }\end{array}$ & $\begin{array}{c}\text { No. of } \\
\text { meetings }\end{array}$ & $\begin{array}{l}\text { No. of meetings } \\
\text { where a record } \\
\text { of proceedings } \\
\text { was available }\end{array}$ & $\begin{array}{c}\text { Date(s) of } \\
\text { meeting(s) } \\
\text { where a } \\
\text { record of } \\
\text { proceedings } \\
\text { was available* }\end{array}$ & $\begin{array}{c}\text { Summary of topic(s) } \\
\text { discussed }\end{array}$ & Summary of recommendation(s)† \\
\hline Opioids SAP & 1 & 1 & $\begin{array}{l}\text { Nov. } 15,2016 \\
\text { and Nov. } 16 \\
2016\end{array}$ & $\begin{array}{l}\text { - Public information } \\
\text { about opioid } \\
\text { overdose and } \\
\text { addiction } \\
\text { - Risk management } \\
\text { plan for opioids }\end{array}$ & $\begin{array}{l}\text { - A warning sticker should be placed on } \\
\text { prescriptions for opioids to highlight the issues } \\
\text { of physical dependence, addiction and } \\
\text { overdose. } \\
\text { - Industry involvement in risk management plans } \\
\text { and educational programs should be monitored } \\
\text { and limited. }\end{array}$ \\
\hline $\begin{array}{l}\text { Isotretinoin risk } \\
\text { management } \\
\text { SAP }\end{array}$ & 1 & 1 & Nov. 17, 2017 & $\begin{array}{l}\text { - Pregnancy prevention } \\
\text { program for } \\
\text { isotretinoin }\end{array}$ & $\begin{array}{l}\text { - Although there is no evidence to show that the } \\
\text { Canadian pregnancy prevention program is not } \\
\text { ineffective, improvements should be made. }\end{array}$ \\
\hline
\end{tabular}

some of the declared interests were misclassified on the website. Given that meeting-specific declarations are not available, interests could have been with the company marketing the product, a competitor or another third party. Some members may have undeclared direct and indirect financial interests. ${ }^{18}$ The 3 types of indirect financial interests were combined into a single category because a lack of data meant that it was not possible to link interests with particular companies to individual members' voting patterns. Different types of intellectual interests were combined for a similar reason.

\section{Conclusion}

Indirect financial interests and intellectual interests are widespread on SACs and SAPs. Biases in voting as a result of interests could influence the quality of the advice that SAC/SAP members give and the sales of products. There are differences between clinical practice guideline committees and SACs/ SAPs, but they are both expected to produce unbiased information. Health Canada could follow the Institute of Medicine recommendations about guideline panels in constituting its SACs/SAPs. Health Canada could also publicly release all of the information about direct and indirect financial interests that is on the Affiliations and Interests Declaration Form for Advisory Body Members along with the date when the declarations were made. In addition, the Canadian government could supplement the information that individual experts report by requiring companies to report all transfers of value to doctors $^{19}$ and other regulated health care professionals. This change would help to ensure that all financial conflicts are disclosed. (Some of the committee and panel members are not regulated health care professionals and therefore this reporting requirement would not cover their interactions with industry.) Finally, Health Canada could record the votes of individual committee and panel members and provide a transcript of meetings so that statistical analyses can be done to investigate whether voting patterns are linked to different types of financial interests with particular companies and to different types of intellectual interests.

\section{References}

1. Scientific/expert advisory committees. Ottawa: Health Canada; 2011. Available: www.canada.ca/en/health-canada/services/drugs-health-products/drug-products/ scientific-expert-advisory-committees.html (accessed 2018 Dec. 17).

2. Scientific/expert advisory panels. Ottawa: Health Canada; 2011. Available: www.canada.ca/en/health-canada/services/drugs-health-products/drug-products/ scientific-expert-advisory-panels.html (accessed 2018 Dec. 17).

3. Scientific experts database - registration page 1. Ottawa: Health Canada; 2018. Available: https://erci-iace.hc-sc.gc.ca/erci-iace/index-eng.jsp (accessed 2018 Dec. 17).

4. Chemicals Management Plan Science Committee. Affiliations and interests declaration. Ottawa: Health Canada; 2017. Available: www.canada.ca/content/ dam/hc-sc/documents/services/chemical-substances/chemicals-management -plan/form-affil-form-eng.pdf (accessed 2018 Dec. 17).

5. Health Products and Food Branch. Guidance on advisory bodies. Ottawa: Health Canada; 2007. Available: http://publications.gc.ca/collections/collection_2014/ sc-hc/H164-172-2007-eng.pdf (accessed 2018 Dec. 17).

6. Pham-Kanter G. Revisiting financial conflicts of interest in FDA advisory committees. Milbank Q 2014;92:446-70.

7. Scientific advisory bodies. Ottawa: Health Canada; 2012. Available: www. canada.ca/en/health-canada/services/drugs-health-products/drug-products/ scientific-expert-advisory-panels/scientific-advisory-bodies.html (accessed 2018 Dec. 17).

8. Completed or active — scientific advisory bodies. Ottawa: Health Canada; 2017. Available: www.canada.ca/en/health-canada/services/drugs-health-products/ drug-products/scientific-expert-advisory-committees/completed-active.html (accessed 2018 Dec. 17).

9. Bero LA, Grundy Q. Why having a (nonfinancial) interest is not a conflict of interest. PLoS Biol 2016;14:e2001221.

10. Bero L. What is in a name? Nonfinancial influences on the outcomes of systematic reviews and guidelines. 7 Clin Epidemiol 2014;67:1239-41.

11. DeJong C, Aguilar T, Tseng C-W, et al. Pharmaceutical industry-sponsored meals and physician prescribing patterns for Medicare beneficiaries. $7 A M A$ Intern Med 2016;176:1114-22.

12. Clinical practice guidelines we can trust. Washington (DC): Institute of Medicine; 2011.

13. Wood SF, Mador J. Uncapped conflict of interest? Science 2013;340:1172-3.

14. Guidance for the public, FDA advisory committee members, and FDA staff: public availability of advisory committee members' financial interest information and waivers: final guidance. Rockville (MD): US Department of Health and Human Services Food and Drug Administration; 2014. Available: www. fda.gov/downloads/regulatoryinformation/guidances/ucm295372.pdf (accessed 2018 Dec. 17).

15. Lenzer J. When is a point of view a conflict of interest? $B M 72016 ; 355$ :i6194

16. Code of practice for chairmen and members of the Commission on Human Medicines, certain committees and expert advisory groups. London (UK): Medicines \& Healthcare products Regulatory Agency; 2015. Available: https://assets 
.publishing.service.gov.uk/government/uploads/system/uploads/attachment data/file/440853/CHM_code_of_practice.pdf (accessed 2018 Dec. 17).

17. Conflict of interest guidelines for CADTH expert committee and panel members. Ottawa: Canadian Agency for Drugs and Technology in Health; 2011. Available: www.cadth.ca/sites/default/files/corporate/corp_committees/ cadth_ coi_guidelines_cedc_members_e.pdf (accessed 2018 Dec. 17).

18. Khan R, Scaffidi M, Rumman A, et al. Prevalence of financial conflicts of interest among authors of clinical guidelines related to high-reevenue medications. FAMA Intern Med 2018;178:1712-5.

19. Rosenthal M, Mello M. Sunlight as disinfectant - new rules on disclosure of industry payments to physicians. N Engl F Med 2013;368:2052-4.

Competing interests: In 2015-2018, Joel Lexchin was a paid consultant on 3 projects: one looking at indication-based prescribing (US Agency for Healthcare Research and Quality), a second to develop principles for conservative diagnosis (Gordon and Betty Moore Foundation) and a third deciding what drugs should be provided free of charge by general practitioners (Government of Canada, Ontario Strategy for PatientOriented Research Support Unit and the St. Michael's Hospital Foundation). He also received payments for being on a panel that discussed a pharmacare plan for Canada (Canadian Institute, a for-profit organization), being on a panel at the American Diabetes Association, giving a talk at the Toronto Reference Library and writing a brief for a law firm on the effects of promotion on prescribing. He is currently a member of research groups that are receiving money from the Canadian Institutes of Health Research and the Australian National Health and Medical Research Council. He is a member of the Foundation Board of Health Action International and the Board of Canadian Doctors for Medicare.

Affiliations: School of Health Policy and Management, York University, and University Health Network and Faculty of Medicine, University of Toronto, Toronto, Ont.

Acknowledgment: The author thanks Catherine Oliver for verifying the extracted data.

Supplemental information: For reviewer comments and the original submission of this manuscript, please see www.cmajopen.ca/content $/ 7 / 2 /$ E334/suppl/DC1. 